\title{
Psychometric properties of the Brazilian Portuguese version of the Obsessive-Compulsive Inventory - Revised (OCI-R)
}

\section{Propriedades psicométricas da versão em português do Brasil da Obsessive-Compulsive Inventory - Revised (OCI-R)}

\author{
Fernanda P. Souza, ${ }^{1}$ Edna B. Foa, ${ }^{2}$ Elisabeth Meyer, ${ }^{1}$ Kátia G. Niederauer, ${ }^{1}$ Aristides V. Cordioli ${ }^{1}$ \\ ${ }^{1}$ Anxiety Disorders Program, Department of Psychiatry, Universidade Federal do Rio Grande do Sul (UFRGS), Porto Alegre, RS, Brazil \\ ${ }^{2}$ Center for the Treatment and Study of Anxiety, Department of Psychiatry, University of Pennsylvania, Philadelphia, PA, USA
}

\begin{abstract}
Objective: The present study was designed to evaluate the psychometric properties of the Brazilian Portuguese version of the ObsessiveCompulsive Inventory - Revised. Method: The Obsessive-Compulsive Inventory - Revised was administered to a total of 260 participants: a clinical sample of 130 patients with anxiety disorders (64 with a diagnosis of obsessive-compulsive disorder patients, 33 diagnosed with social phobia, and 33 with panic disorder) and a sample of 130 non-clinical subjects. Results: The findings indicate that the Obsessive-Compulsive Inventory - Revised is a valid measure for identifying and assessing the severity of the six symptom subtypes in obsessive-compulsive disorder. The original factor structure of the instrument was replicated in an exploratory factor analysis. Test-retest reliability was examined using data from 64 obsessive-compulsive disorder patients who completed the inventory on two different occasions. In each sample, the overall and subscale scores showed moderate to good internal consistency, good convergent and divergent validity, and sensitivity to changes resulting from cognitivebehavioral group therapy. Conclusion: Our findings indicate that the Brazilian Portuguese version of the Obsessive-Compulsive Inventory Revised retains the psychometric properties of its original version and the Spanish, German and Icelandic versions.
\end{abstract}

Descriptors: Obsessive-compulsive disorder; Evaluation; Symptoms; Anxiety disorders; Brazil

\section{Resumo}

Objetivo: O presente estudo foi delineado para avaliar as propriedades psicométricas da versão em português do Brasil do Obsessive-Compulsive Inventory - Revised. Método: O Obsessive-Compulsive Inventory Revised foi aplicado em um total de 260 individuos: em uma amostra clinica de 130 pacientes (64 pacientes com transtorno obsessivo-compulsivo, 33 pacientes com fobia social e 33 pacientes com transtorno do pânico) mais uma amostra não clínica de 130 sujeitos. Resultados: Os resultados indicam que o Obsessive-Compulsive Inventory - Revised é uma medida válida para identificar e avaliar a severidade dos seis subtipos de sintomas do transtorno obsessivo-compulsivo. A estrutura fatorial do instrumento foi replicada em uma análise fatorial exploratória. A confiabilidade teste-reteste foi examinada usando os dados de 64 pacientes com transtorno obsessivo-compulsivo que completaram o inventário em dois momentos diferentes. Em cada amostra, os escores total e das subescalas mostraram consistência interna de boa a moderada, boa validade concorrente e discriminante, e sensibilidade para as mudanças da terapia cognitivo-comportamental em grupo. Conclusão: Nossos achados indicam que a versão para o português do Brasil do ObsessiveCompulsive Inventory - Revised manteve as propriedades psicométricas da versão original e das versões em espanhol, alemão e islandês.

Descritores: Transtorno obsessivo-compulsivo; Avaliação; Sintomas; Transtornos de ansiedade; Brasil

\section{Introduction}

Obsessive-compulsive disorder (OCD) is characterized by repetitive behaviors that develop as attempts to relieve the anxiety provoked by intrusive and persistent thoughts. Patients may present one or more OCD symptoms at the same time (for instance, concerns about contamination and washing) and several studies have reported the importance of condensing these symptoms into specific subgroups. ${ }^{1-3}$ In addition, the intensity of symptoms may vary within each subtype.
One measure that has been designed to correspond with the symptom-based structural model of OCD is the ObsessiveCompulsive Inventory - Revised (OCI-R), ${ }^{4}$ an 18 -item selfreport instrument which is a revised and shortened version of the Obsessive-Compulsive Inventory (OCI). ${ }^{5}$ The1 8 items of the shortened version are rated on a five-point Likert scale that supplies scores on six subscales, and it offers improvements over the first version in three aspects: (1) it eliminates the redundant scale of 
"frequency"; (2) it simplifies subscales scores; and (3) it reduces overlapping subscales. It should be pointed out that the OCI-R has demonstrated a higher level of reliability than the longer version, ${ }^{4}$ and was proven to have good psychometric properties in both clinical and non-clinical samples. Also, the OCI-R showed a satisfactory discrimination between OCD patients and anxious and non-anxious individuals. ${ }^{4}$ In addition to providing an overall score, the OCI-R also scores six dimensions individually: checking, washing, ordering, hoarding, obsessing, and neutralizing.

Some studies with American samples have examined the psychometric properties of the OCI-R. Huppert et al. validated the subscales in a clinical sample of 186 patients diagnosed with OCD and 17 patients diagnosed with generalized anxiety disorder (GAD), and the results indicated that the subscales of the OCI-R were valid measures of six symptom subtypes of OCD. ${ }^{6}$ Hajcak et al. studied the inventory in two samples of undergraduate students and found that the OCI-R had good internal consistency, convergent validity, and test-retest reliability. ${ }^{7}$ Abramowitz et al. replicated and extended previous OCI-R findings with OCD patients and patients with other anxiety disorders and recommended the inventory as an empirically validated instrument that can be used in a range of OCD-related clinical and research settings. ${ }^{8}$

Several studies carried out in different countries examined the psychometric properties of the OCI-R, with results consonant with those originally found by Foa et al. ${ }^{4}$ The Spanish research by Fullana et al. based on a non-clinical student sample, showed that the total scale and each of the subscales presented moderate to good internal consistency and test-retest reliability, and moderate convergent validity and good divergent validity. ${ }^{9}$ Gönner et al. examined the outcomes obtained from a sample of patients with OCD, other anxiety disorders, and depressive disorders with the German version of the inventory, and found good convergent, divergent, and known-groups validity for the full scale and the subscales in the three samples. ${ }^{10}$ Smári et al. administered the Icelandic OCI-R version to a sample of college students and found strong psychometric properties of the scale for this population. ${ }^{11}$

Although the OCI-R has been translated into Portuguese, its psychometric properties have not been examined in clinical and non-clinical Brazilian samples. This study addressed the psychometric properties and factor structure of the Brazilian Portuguese version of the OCI-R (total scale and subscales) in a sample comprising patients diagnosed with OCD, patients with other anxiety disorders, and healthy controls. We conducted a confirmatory factor analysis of the OCI-R and investigated the evidence for its convergent and divergent validity in comparison with another measure of obsessive-compulsive symptoms (YaleBrown Obsessive-Compulsive Scale - Y-BOCS), a measure of depression symptoms (Beck Depression Inventory - BDI) and a measure of anxiety symptoms (Beck Anxiety Inventory - BAI). Apart from the above, the test-retest reliability of the OCI-R total scale and subscales was investigated. In addition, we wished to examine the sensitivity of the OCI-R administered prior to and after cognitive behavioral group therapy (CBGT) for OCD outpatients in comparison with the Y-BOCS. Finally, we compared its psychometric features with the original and adapted versions of the scale.

\section{Method}

\section{Participants}

The sample consisted of 260 adults, of whom 64 were outpatients diagnosed with OCD, 33 were outpatients with panic disorder (PD), 33 were outpatients with social phobia (SP), and 130 were healthy controls (HC) according to DSM-IV criteria.

\section{Procedures}

All participants were evaluated by trained master level psychologists with extensive clinical experience in OCD. Participants were evaluated using a clinical interview and the Brazilian version $^{12}$ of the Structured Clinical Interview for DSMIV (SCID-IV). ${ }^{13}$ Inclusion criteria were established as follows: (1) only OCD, PD and SP adult outpatients selected among those currently undergoing treatment in the Anxiety Disorder Outpatient Program (PROTAN) of the Hospital de Clínicas de Porto Alegre (HCPA), Universidade Federal de Rio Grande do Sul (UFRGS), Brazil, who had been diagnosed at the time of admission and had already been evaluated and considered eligible to begin the treatment were included; (2) patients with PD or SP were only included if they were not diagnosed with comorbid OCD; (3) absence of psychiatric disorders for HC.

The 64 OCD patients completed the Brazilian version ${ }^{14}$ of the $\mathrm{Y}_{-\mathrm{BOCS}}{ }^{15}$ in order to confirm diagnosis. All OCD patients attended 12 weekly sessions of CBGT as part of the PROTAN. In addition to the OCI-R, patients were also assessed with theY-BOCS, the Brazilian version ${ }^{16}$ of the $\mathrm{BDI}^{17}$ and the Brazilian version ${ }^{16}$ of the BAI. ${ }^{18}$

SP and PD patients were diagnosed using the SCID-IV ${ }^{13}$ and referred to treatment in the PROTAN. The control group comprised healthy volunteers matched to treatment in age, education, and gender. HC were all employees at the HCPA and were also assessed using the SCID-IV. ${ }^{13}$

All sample subsets (SP, PD, and HC) completed the same instruments administered to the OCD sample.

CBGT was based on a structured manual-based approach developed by one of the authors (AVC) and used in previous trials. ${ }^{19-21}$ CBGT consisted of 12 weekly two-hour sessions. The treatment approach emphasizes psycho-education, ERP techniques, cognitive techniques to change dysfunctional thoughts and beliefs, strategies to prevent relapses, and group techniques. Details on the manual can be found elsewhere. ${ }^{20,22}$

Data were collected between March 2006 and July 2007. The Ethics Committee of the HCPA approved the research protocol (Process: 05/505). Written informed consent was obtained from all participants after a thorough description of the study and reassurance was given that their decision to participate or not in the study would not interfere with their treatment. 


\section{Measures}

The following scales were used to evaluate outcomes:

1) OCI-R: ${ }^{4}$ translated and adapted to Brazilian Portuguese by Souza et al. ${ }^{23}$ This is an 18 -item self-report questionnaire which assesses the distress associated with obsessive-compulsive symptoms. In the original version, it has shown good psychometric properties in patients with anxiety disorders. A complete description of the translation and back-translation procedures is available elsewhere ${ }^{23}$ and the final version of the OCI-R in Brazilian Portuguese is available upon request.

2) Y-BOCS: ${ }^{15}$ translated and adapted to Brazilian Portuguese by Asbahr et al. ${ }^{14}$ This scale assesses obsessions and compulsions and is considered to be the "gold standard" for the evaluation of the severity of symptoms. It is based on a Likert scale ranging from 0 (without symptoms) to 4 (very severe). Five questions evaluate obsession and another five measure compulsive features.

3) BDI: ${ }^{17}$ translated, adapted and validated for the Brazilian population by Gorenstein et al. ${ }^{16}$ This instrument gauges the presence and intensity of depressive symptoms. It is a self-report scale with 21 items, each with four severity alternatives (minimal, mild, moderate or severe).

4) Structured Clinical Interview for DSM-IV (SCID-IV): proposed in 1997 by First et al. and translated and adapted to Portuguese by Tavares, it is a semi-structured interview developed for use in research and for the diagnosis of Axis I disorders, according to DSM-IV criteria. ${ }^{12,13}$

5) BAI: ${ }^{18}$ translated, adapted, and validated for the Brazilian population by Gorenstein et al. This is a self-report scale with 21 items commonly used to evaluate clinical anxiety. It returns a total score which varies from 0 to $63 .{ }^{16}$

\section{Statistical analysis}

Statistical analyses were carried out with the Statistical Package for the Social Sciences (SPSS) version 12.0 for Windows (SPSS
Inc., Chicago, Illinois). Means and standard deviations (symmetric distribution) or median and interquartile ranges (asymmetric distribution) were computed for all measures and differences between OCD patients, patients with other anxiety disorders, and $\mathrm{HC}$ were examined. We tested the equality of the distributions using the non-parametric Kolmogorov-Smirnov test. Analyses of variance (ANOVA) were conducted using Tukey test adjusted for multiple comparisons between groups. The Kruskal-Wallis test was applied to asymmetric data and the analysis was completed using the MannWhitney test. In order to control for type I errors, the software package Programs for Epidemiologists (PEPI), version 4.0, was used to apply Finner adjustment to p values. Pearson's Chi square was used to assess associations between qualitative variables. In cases of statistical significance, the adjusted residues test was applied. In addition, Cronbach's alpha was calculated for each subscale to determine internal consistency. Spearman's correlation coefficient was calculated to assess test-retest reliability and agreement between scales. The Wilcoxon test was used to evaluate pre-/post-treatment changes in the sample of OCD patients. Test-retest reliability was evaluated using the same interval as in the original study (seven days). ${ }^{4}$ To examine the six-factor structure of the OCI-R, a factor analysis with varimax rotation was conducted. Statistical associations were considered significant when $\mathrm{p}<0.05$.

\section{Results}

\section{Subjects}

The sample comprised 187 females and 73 males. Since gender differences were not our primary concern, male and female samples were not analyzed separately. Age and other sociodemographic variables for the whole samples are presented in Table 1.

\section{Internal consistency}

Our finding demonstrated a high internal consistency for the whole OCI-R in all samples, ranging from 0.70 (SP sample)

Table 1 - Demographic characteristics for the whole sample

\begin{tabular}{|c|c|c|c|c|c|}
\hline Characteristic & $\begin{array}{l}\text { Total sample } \\
\qquad(n=260)\end{array}$ & $\begin{array}{c}\text { OCD } \\
(n=64)\end{array}$ & $\begin{array}{l}\text { Social phobia } \\
\quad(n=33)\end{array}$ & $\begin{array}{l}\text { Panic disorder } \\
\quad(n=33)\end{array}$ & $\begin{array}{l}\text { Controls } \\
(n=130)\end{array}$ \\
\hline $\begin{array}{l}\text { Age (in years) Mean (M); } \\
\text { Standard deviation (SD) }\end{array}$ & $36.4 ; 11.7$ & $38.9^{\mathrm{a}} ; 12$ & $31.6^{\mathrm{b}} ; 11.9$ & $35.9^{a b} ; 9.98$ & $36.5^{a b}, 11.4$ \\
\hline \multicolumn{6}{|l|}{ Gender - n (\%) } \\
\hline Male & $73(28.1)$ & $13(20.3)$ & $13(39.4)$ & $11(33.3)$ & $36(27.7)$ \\
\hline Female & $187(71.9)$ & $51(79.7)$ & $20(60.6)$ & $22(66.7)$ & $94(72.3)$ \\
\hline \multicolumn{6}{|l|}{ Marital status - n (\%) } \\
\hline Single & $108(41.5)$ & $23(35.9)$ & $18(54.5)$ & $11(33.3)$ & $56(43.1)$ \\
\hline Married & $123(47.3)$ & $35(54.7)$ & $12(36.4)$ & $19(57.6)$ & $57(43.8)$ \\
\hline Divorced & $25(9.6)$ & $4(6.3)$ & $3(9.1)$ & $3(9.1)$ & $15(11.5)$ \\
\hline Widow & $4(1.5)$ & $2(3.1)$ & $0(0.0)$ & $0(0.0)$ & $2(1.5)$ \\
\hline \multicolumn{6}{|l|}{ Education, years - n (\%) } \\
\hline$\leq 8$ & $28(10.8)$ & $5(7.8)$ & $5(15.2)$ & $4(12.1)$ & $14(10.8)$ \\
\hline $9-11$ & $94(36.2)$ & $18(28.1)$ & $13(39.4)$ & $16(48.5)$ & $47(36.2)$ \\
\hline$>11$ & $138(53.1)$ & $41(64.1)$ & $15(45.5)$ & $13(39.4)$ & $69(53.1)$ \\
\hline
\end{tabular}

$O C D=$ Obsessive-compulsive disorder. In each line, different letters indicate statistically significant difference $(p<0.05)$ according to the Tukey test. 
Table 2 - Cronbach's $\alpha$ for the OCI-R total score and subscales, for the whole sample and each subset

\begin{tabular}{lccccc}
\hline Subscales & $\begin{array}{c}\text { Total sample } \\
(\mathbf{n = 2 6 0 )}\end{array}$ & $\begin{array}{c}\text { OCD } \\
(\mathbf{n = 6 4 )}\end{array}$ & $\begin{array}{c}\text { Social phobia } \\
(\mathbf{n}=\mathbf{3 3})\end{array}$ & $\begin{array}{c}\text { Panic disorder } \\
(\mathbf{n}=\mathbf{3 3})\end{array}$ & $\begin{array}{c}\text { Controls } \\
(\mathbf{n}=\mathbf{1 3 0})\end{array}$ \\
\hline Checking & 0.931 & 0.831 & 0.810 & 0.503 & 0.807 \\
Hoarding & 0.896 & 0.898 & 0.849 & 0.317 & 0.680 \\
Neutralizing & 0.733 & 0.608 & 0.722 & 0.387 & 0.666 \\
Obsessing & 0.764 & 0.477 & 0.495 & 0.357 & 0.612 \\
Ordering & 0.923 & 0.840 & 0.508 & 0.679 & 0.627 \\
Washing & 0.881 & 0.844 & 1.000 & -0.090 & 0.815 \\
Total score & 0.949 & 0.829 & 0.703 & 0.779 & 0.847 \\
\hline
\end{tabular}

OCD $=$ Obsessive-compulsive disorder

to 0.94 (OCD sample). All subscales presented high internal consistency for the whole sample, and good internal consistency for patients with OCD and SP, with four out of six coefficients exceeding 0.70. In the PD sample, the subscales had low to moderate internal consistency, except for the ordering subscale, which demonstrated good internal consistency. In relation to the control group, good internal consistency was found for the whole OCI-R and the washing and checking subscales and moderate for the remaining subscales. Alpha coefficients are shown in Table 2.

\section{Test-retest reliability}

Sixty-four OCD patients were included in this phase of the study. A non-significant difference $(\mathrm{p}=0.085)$ was found between test $($ median $=29 ; \mathrm{P} 25=10 ; \mathrm{P} 75=41.5)$ and retest $($ median $=27$; $\mathrm{P} 25=10 ; \mathrm{P} 75=42.5)$. The test-retest reliability for the overall score was 0.98 , and for the subscales the correlations ranged between 0.95 and 0.99 .

\section{Convergent and divergent validity}

Spearman correlation coefficients between the OCI-R and the Y-BOCS, BDI, and BAI scores are presented in Table 3. Data from these scales were positively correlated with the OCI-R total score and all the other measures. Our findings demonstrated a moderate correlation between the OCI-R obsession subscale and

Table 3 - Spearman correlation between the Y-BOCS, BDI, BAI and OCI-R

\begin{tabular}{lcc}
\hline \multirow{2}{*}{ Scales } & \multicolumn{2}{c}{ OCI-R } \\
\cline { 2 - 3 } & Total & Obsession \\
\hline Y-BOCS & - \\
Total & $0.471^{*}$ & $0.310^{* * *}$ \\
Obsessions & $0.400^{* *}$ & - \\
Compulsions & $0.473^{*}$ & - \\
BAI & $0.382^{*}$ & - \\
BDI & $0.350^{*}$ & \\
\hline OCl-R = Obsessive-Compulsive Inventory-Revised; Y-BOCS $=$ \\
Yale-Brown Obsessive Compulsive Scale; BAI = Beck Anxiety \\
Inventory; BDI = Beck Depression Inventory. \\
${ }^{*} p<0.001 ;{ }^{* *} p<0.01 ;{ }^{* * *} p<0.05$
\end{tabular}

the Y-BOCS obsession score, and a low correlation with the BDI and the BAI. The highest correlation was found between the total scores in the OCI-R and the Y-BOCS.

In order to examine the ability of the OCI-R to discriminate the OCD sample from other samples we compared medians and interquartile ranges using the Kruskal-Wallis $\mathrm{H}$ test. The same ability was also evaluated by applying the Mann-Whitney test with Finner adjustment. As shown in Table 4, the Kruskal-Wallis test results showed differences in the total score for all samples. The Mann-Whitney test demonstrated that OCD patients were significantly more distressed than individuals from other samples according to both the total scale and all subscales.

\section{Sensitivity to treatment-related changes in the scales used to evaluate OCD patients}

Sensitivity to change was evaluated by comparing changes in the total score of the OCI-R administered before and after CBGT and by comparing these to changes in Y-BOCS scores. Median $(\mathrm{m})$ and interquartile ranges (iq) of the OCI-R total score before $(\mathrm{m}=33.5 ; \mathrm{iq}=10.5)$ and after $(\mathrm{m}=6.5 ; \mathrm{iq}=10.5)$ treatment were significantly different $(\mathrm{p}<0.001)$. The same level of statistical significance $(\mathrm{p}<0.001)$ was found for the mean and standard deviation in Y-BOCS total scores before $(\mathrm{m}=30.5$; iq $=4.3)$ and after $(\mathrm{m}=9.9$; $\mathrm{iq}=6.2)$ treatment. The association between the Y-BOCS and OCI-R scores was adequate prior to treatment $(\mathrm{r}=$ $0.5 ; \mathrm{p}<0.001)$ and higher after treatment $(\mathrm{r}=0.7 ; \mathrm{p}<0.001)$. The OCI-R also demonstrated a good ability to discriminate between OCD patients and other groups of patients with anxiety disorders, with the exception of the hoarding and ordering subscales.

\section{Exploratory factor analysis of the OCI-R}

To test the factor stability of the six subscales of the OCI-R in the total sample $(\mathrm{N}=260)$, an exploratory factor analysis was performed. The six-factor structure of the OCI-R was confirmed in the sample. The model had a significant chi-square, $\chi^{2}(153, \mathrm{n}=64)=4065, \mathrm{p}<0.001$, and a goodness-of-fit index of 0.918 indicating an excellent fit for the model. As shown in Table 5, all items had very high factor loadings on the factor they belonged to. 
Table 4 - Medians and interquartile ranges for total scores and subscale of the OCI-R for all samples

\begin{tabular}{|c|c|c|c|c|c|}
\hline \multirow[t]{2}{*}{ Subscales } & $\begin{array}{c}\text { OCD } \\
(n=64)\end{array}$ & $\begin{array}{l}\text { Social phobia } \\
\quad(n=33)\end{array}$ & $\begin{array}{l}\text { Panic disorder } \\
\quad(\mathrm{n}=\mathbf{3 3})\end{array}$ & $\begin{array}{l}\text { Controls } \\
(n=130)\end{array}$ & \multirow[t]{2}{*}{$\mathrm{p}^{*}$} \\
\hline & Mdn (P25 to 75$)$ & Mdn (P25 to P75) & Mdn (P25 to 75$)$ & Mdn (P25 to 75$)$ & \\
\hline Checking & $8^{a}(4.3$ to 11.8$)$ & $0^{b}(0$ to 0.5$)$ & $0^{\mathrm{b}}(0$ to 1$)$ & $0^{\mathrm{b}}(0$ to 0$)$ & $<0.001$ \\
\hline Hoarding & $4^{a}(0$ to 9$)$ & $0^{b c}(0$ to 1.5$)$ & $0^{\mathrm{b}}(0$ to 2$)$ & $0^{c}(0$ to 0$)$ & $<0.001$ \\
\hline Neutralizing & $2^{a}(0$ to 5$)$ & $0^{b}(0$ to 0$)$ & $0^{b}(0$ to 0$)$ & $0^{\mathrm{b}}(0$ to 0$)$ & $<0.001$ \\
\hline Obsessing & $7^{a}(5$ to 8$)$ & $0^{b}(0$ to 1$)$ & $0^{b}(0$ to 2$)$ & $0^{c}(0$ to 0$)$ & $<0.001$ \\
\hline Ordering & $8^{a}(4$ to 11$)$ & $0^{b}(0$ to 0.5$)$ & $0^{b}(0$ to 1.5$)$ & $0^{\mathrm{b}}(0$ to 1$)$ & $<0.001$ \\
\hline Washing & $4^{a}(0$ to 8.8$)$ & $0^{b}(0$ to 0$)$ & $0^{b}(0$ to 0$)$ & $0^{\mathrm{b}}(0$ to 0$)$ & $<0.001$ \\
\hline Total score & $33.5^{a}$ (22.5 to 43$)$ & $2^{b}(0$ to 5$)$ & $2^{b}(0$ to 6.5$)$ & $0^{c}(0$ to 2$)$ & $<0.001$ \\
\hline
\end{tabular}

$O C D=$ Obsessive-compulsive disorder. Within each row, different letters in superscript indicate significant differences $(p<0.05)$ according to the Mann-Whitney test with $p$ values subjected to Finner adjustment.

* Value obtained using the Kruskal-Wallis $H$ test.

\section{Discussion}

The main goal of this study was to examine the psychometric properties of the Brazilian Portuguese version of the OCI-R. Therefore, a clinical sample including three groups with different anxiety disorders and a non-clinical sample were recruited. We also aimed at examining the performance of each subscale in the OCD sample in addition to observing the results before and after CBGT. Moreover, we correlated the OCI-R with other commonly used measures. Additionally, we compared our results with those of the original version, ${ }^{4}$ the Spanish version ${ }^{9}$ and the German version ${ }^{10}$ of the OCI-R.

Overall, the Brazilian Portuguese version of the OCI-R displayed excellent psychometric properties. The findings indicated that our patients had higher OCI-R mean $(M)$ scores $(M=33.0$; $\mathrm{SD}=13.9)$ than those in the samples studied by Huppert et al. $(M=26.3 ; S D=12.8)$, Gönner et al. $(M=26.1 ; S D=13.3)$, Foa et al. $(\mathrm{M}=28.0 ; \mathrm{SD}=13.5)$ and Abramowitz et al. $(\mathrm{M}=$ 27.0; SD = 13.2); SD stands for standard deviation. ${ }^{4,6,8,10}$ This suggests that the Brazilian Portuguese version of the OCI-R is a useful screening instrument able to discriminate between patients diagnosed with OCD, patients with other anxiety disorders and healthy individuals.

Concerning the OCI-R subscales, we found internal consistency values for the checking, hoarding, neutralizing and ordering subscale scores in our OCD group similar to those reported by Huppert et al. and higher than those found by Gönner et al. 6,10 When we consulted the results of the Spanish version of the OCI-R, we found very similar estimates for the total score, and for the hoarding, ordering, checking, and neutralizing subscales. Moreover, our results were quite similar to those found by Hajcak et al., only differing in relation to the ordering subscale ( 0.62 in the Brazilian study and 0.84 in the non-clinical sample of students). ${ }^{7}$

Convergent validity was demonstrated by significant correlations between the Brazilian Portuguese versions of the OCI-R and the Y-BOCS. In the OCD sample, the OCI-R total score and all the subscale scores also demonstrated moderate to good convergent validity with the Y-BOCS. Divergent validity was established by low correlations between the OCI-R and the BDI and the BAI, which are instruments that were not specifically developed to assess OCD. These results are in line with previous findings. ${ }^{4,7,8,10}$ In addition, the correlation between the OCI-R obsession subscale and the Y-BOCS was lower in our study as compared to the original version $^{4}(0.53)$, similar to that of the German version ${ }^{10}$ (0.40), and higher than the results published by Abramowitz et al. ${ }^{8}$ (0.22). The correlation with the BDI was similar to the German version $^{10}(0.32)$ and close to the results reported by Hajcak et al. (0.39) and Abramowitz et al. (0.41). ${ }^{7,8}$ In relation to the correlation between the OCI-R and the BAI, the data were similar to those found for the German version ${ }^{10}(0.42)$.

Furthermore, the test-retest reliability for the overall score was excellent and higher than those reported by Hajcak et al. ${ }^{7}(0.7)$ and for the Spanish version ${ }^{1}$ (0.67). On the other hand, the correlations of the subscales were similar to those found by Foa et al. ranging from 0.74 to $0.91 .^{4}$

The OCI-R showed a good ability to assess the effects of treatment in OCD patients and might thus be helpful for measuring treatment outcomes. Our findings are in agreement with those reported by Abramowitz et al. ${ }^{24}$ Additionally, our results demonstrate that the Brazilian Portuguese version of the OCI-R produces results that are quite stable over time. The total score and each subscale had correlation values higher than 0.95 , suggesting that the OCI-R is a reliable tool.

Finally, our exploratory factor analysis suggested an adequate fit for a six-factor structure, thus replicating previous results on the OCI-R in both clinical ${ }^{4,6,8}$ and non-clinical ${ }^{7,9}$ samples.

Some limitations of the present study should be highlighted: (1) the number of patients in each group was small; (2) included participants came from a single center, located in a university hospital; and (3) the sensitivity of the specific subscales to treatment effects remains to be examined.

Further research should investigate the convergent validity of the six subscales of the OCI-R and the corresponding six OCD subtypes derived from the Y-BOCS checklist and, for instance, from the Dimensional Yale-Brown Obsessive-Compulsive Scale 
Table 5 - Factor loadings of the OCI-R from exploratory factor analysis with Varimax rotation on the sample $(n=260)$

\begin{tabular}{|c|c|c|c|c|c|c|}
\hline OCI-R Item & C. & H. & $\mathbf{w}$. & Or. & N. & Ob. \\
\hline $\begin{array}{l}\text { 2. Verifico coisas mais freqüentemente que o necessário. } \\
\text { / check things more often than necessary. }\end{array}$ & 0.73 & 0.29 & 0.21 & 0.37 & 0.19 & 0.13 \\
\hline $\begin{array}{l}\text { 8. Verifico repetidamente portas, janelas gavetas, etc. } \\
\text { I repeatedly check doors, windows, drawers etc. }\end{array}$ & 0.84 & 0.18 & 0.19 & 0.29 & 0.11 & 0.12 \\
\hline $\begin{array}{l}\text { 14. Verifico repetidamente o gás, as torneiras e os interruptores de luz após desligá-los. } \\
\text { I repeatedly check gas and water taps and light switches after turning them off. }\end{array}$ & 0.82 & 0.11 & 0.19 & 0.22 & 0.20 & 0.20 \\
\hline $\begin{array}{l}\text { 1. Tenho guardado tantas coisas que elas atravancam o caminho. } \\
\text { I have saved up so many things that they get in the way. }\end{array}$ & 0.14 & 0.88 & 0.09 & 0.11 & 0.10 & 0.02 \\
\hline $\begin{array}{l}\text { 7. Coleciono coisas de que não preciso. } \\
\text { I collect things I don't need. }\end{array}$ & 0.26 & 0.82 & 0.20 & 0.16 & 0.11 & 0.13 \\
\hline $\begin{array}{l}\text { 13. Evito jogar coisas fora, pois tenho receio de que possa precisar delas mais tarde. } \\
\text { I avoid throwing things away because I am afraid I might need them later. }\end{array}$ & 0.22 & 0.78 & 0.18 & 0.35 & 0.07 & 0.21 \\
\hline 5. Acho difícil (não gosto de) tocar um objeto quando eu sei que ele já foi tocado por & 0.16 & 0.19 & 0.86 & 0.14 & 0.18 & 0.01 \\
\hline
\end{tabular}
estranhos ou certas pessoas.

I find it difficult to touch an object when I know it has been touched by strangers or certain people.

11. Às vezes tenho que me lavar ou me limpar pelo simples fato de me sentir contaminado.

I sometimes have to wash or clean myself simply because I feel contaminated.

17. Lavo minhas mãos com maior freqüência e por mais tempo que o necessário (do que a maioria das outras pessoas).

I wash my hands more often and longer than necessary.

3. Fico perturbado se os objetos não estão arrumados apropriadamente (de maneira adequada).

I get upset if objects are not arranged properly.

9. Perturbo-me se outras pessoas mudam a forma como arrumei as coisas.

I get upset if others change the way I have arranged things.

15. Necessito que as coisas estejam arrumadas em uma certa ordem.

I need things to be arranged in a particular order.

4. Sinto-me compelido a (tenho necessidade de) contar enquanto estou fazendo coisas.

I feel compelled to count while I am doing things.

10. Sinto que tenho que repetir certos números.

I feel I have to repeat certain numbers.

16. Sinto que há números bons e maus.

I feel that there are good and bad numbers.

6. Acho difícil controlar meus próprios pensamentos.

I find it difficult to control my own thoughts.

12. Pensamentos desagradáveis vêm à minha mente contra a minha vontade e não consigo me livrar deles.

I am upset by unpleasant thoughts that come into my mind against my will.

18. Freqüentemente tenho pensamentos sórdidos/sujos (maus ou ruins) e tenho dificuldade de me livrar deles.

I frequently get nasty thoughts and have difficulty in getting rid of them.

Eigenvalue

Total $\%$ of Variance

\begin{tabular}{|c|c|c|c|c|c|}
\hline 0.22 & 0.18 & 0.85 & 0.13 & 0.12 & 0.13 \\
\hline 0.38 & 0.09 & 0.70 & 0.31 & 0.31 & 0.10 \\
\hline 0.47 & 0.23 & 0.13 & 0.74 & 0.23 & 0.06 \\
\hline 0.38 & 0.32 & 0.31 & 0.71 & 0.15 & 0.00 \\
\hline 0.32 & 0.24 & 0.22 & 0.76 & 0.21 & 0.12 \\
\hline 0.03 & 0.33 & 0.15 & 0.28 & 0.67 & -0.20 \\
\hline 0.48 & 0.05 & 0.20 & -0.07 & 0.71 & 0.22 \\
\hline 0.24 & 0.02 & 0.27 & 0.31 & 0.73 & 0.09 \\
\hline 0.03 & 0.34 & 0.31 & 0.35 & 0.21 & 0.66 \\
\hline 0.10 & 0.42 & 0.31 & 0.23 & 0.23 & 0.64 \\
\hline 0.20 & 0.19 & 0.12 & 0.09 & 0.04 & 0.91 \\
\hline 3.89 & 2.91 & 2.64 & 2.56 & 1.96 & 1.11 \\
\hline 21.6 & 16.2 & 14.7 & 14.2 & 10.9 & 6.15 \\
\hline
\end{tabular}

OCI-R = Obsessive-Compulsive Inventory-Revised; $\mathrm{H} .=$ Hoarding; Or. = Ordering; Ob. = Obsessing; $C=$ Checking/doubting; $W .=$ Washing; N. = Mental neutralizing.

(DY-BOCS $)^{3}$ which evaluates obsessive-compulsive symptoms according to six specific dimensions. Additional research is required to establish adequate cut-off scores for Brazilian clinical and nonclinical samples.

In summary, the Brazilian Portuguese version of the OCI-R strongly correlates with the original version of the scale and with versions in other languages, and can be recommended as a valid measure. It is appropriate to be used with clinical and non-clinical populations, and for clinical and research purposes. 


\section{Disclosures}

\begin{tabular}{|c|c|c|c|c|c|c|c|}
\hline $\begin{array}{l}\text { Writing group } \\
\text { member }\end{array}$ & Employment & $\begin{array}{l}\text { Research } \\
\text { grant }^{1}\end{array}$ & $\begin{array}{c}\text { Other research grant } \\
\text { or medical } \\
\text { continuous } \\
\text { education }\end{array}$ & $\begin{array}{l}\text { Speaker's } \\
\text { honoraria }\end{array}$ & $\begin{array}{l}\text { Ownership } \\
\text { interest }\end{array}$ & $\begin{array}{l}\text { Consultant/ } \\
\text { Advisory } \\
\text { board }\end{array}$ & Other ${ }^{3}$ \\
\hline $\begin{array}{l}\text { Fernanda P. } \\
\text { Souza }\end{array}$ & HCPA & - & - & - & - & - & - \\
\hline Edna B. Foa & $\begin{array}{l}\text { University of } \\
\text { Pennsylvania }\end{array}$ & - & - & - & - & - & - \\
\hline Elisabeth Meyer & HCPA & $\mathrm{CNPq}$ & - & $\begin{array}{l}\text { Speeches } \\
\text { and courses* }\end{array}$ & - & - & - \\
\hline $\begin{array}{l}\text { Kátia G. } \\
\text { Niederauer }\end{array}$ & HCPA & - & - & - & - & - & - \\
\hline $\begin{array}{l}\text { Aristides V. } \\
\text { Cordioli }\end{array}$ & $\begin{array}{l}\text { UFRGS } \\
\text { HCPA }\end{array}$ & - & - & $\begin{array}{l}\text { Speeches } \\
\text { and courses* }\end{array}$ & - & - & Copyright* \\
\hline
\end{tabular}

* Modest

** Significant

*** Significant: Amounts given to the author's institution or to a colleague for research in which the author has participation, not directly to the author.

Note: HCPA = Hospital de Clínicas de Potro Alegre; UFRGS = Universidade Federal do Rio Grande do Sul; CNPq= Conselho Nacional de Desenvolvimento Científico e Tecnológico.

For more information, see Instructions for Authors.

\section{References}

1. Fullana MA, Tortella-Feliu M, Caseras X, Taberner J, Torrubia R, MataixCols D. Temporal stability of obsessive-compulsive symptom dimensions in an undergraduate sample: a prospective 2-year follow-up study. Behav Modif. 2007;31(6):815-24.

2. Mataix-Cols D, Fullana MA, Alonso P, Menchón JM, Vallejo J. Convergent and discriminant Validity of the Yale-Brown Obsessive-Compulsive Scale Symptom Checklist. Psychother Psychosom. 2004;73(3):190-6.

3. Rosario-Campos MC, Miguel EC, Quatrano S, Chacon P, Ferrao Y, Findley D, Katsovich L, Scahill L, King RA, Woody SR, Tolin D, Hollander E, Kano Y, Leckman JF. The Dimensional Yale-Brown Obsessive-Compulsive Scale (DYBOCS): an instrument for assessing obsessive-compulsive symptom dimensions. Mol Psychiatry. 2006;11(5):495-504.

4. Foa EB, Huppert JD, Leiberg S, Langner R, Kichic R, Hajcak G, Salkovskis $\mathrm{PM}$. The Obsessive-Compulsive Inventory: development and validation of a short version. Psychol Assess. 2002;14(4):485-96.

5. Foa EB, Kozak MJ, Salkovskis PM. The validation of a new ObsessiveCompulsive Disorder Scale: The Obsessive-Compulsive Inventory. Psychol Assess. 1998;10:206-14.

6. Huppert JD, Walther MR, Hajcak G, Yadin E, Foa EB, Simpson HB, Liebowitz MR. The OCI-R: validation of the subscales in a clinical sample. J Anxiety Disord. 2007;21(3):394-406

7. Hajcak G, Huppert JD, Simons RF, Foa EB. Psychometric properties of the OCI-R in a college sample. Behav Res Ther. 2004;42(1):115-23.

8. Abramowitz JS, Deacon BJ. Psychometric properties and construct validity of the Obsessive-Compulsive Inventory-Revised: replication and extension with a clinical sample. J Anxiety Disord. 2006;20(8):1016-35.

9. Fullana MA, Tortella-Feliu M, Caseras X, Andión O, Torrubia R, Mataix-Cols D. Psychometric properties of the Spanish version of the Obsessive-Compulsive Inventory-Revised in a non-clinical sample. J Anxiety Disord. 2005;19(8):893-903. 10. Gönner S, Leonhart R, Ecker W. The Obsessive-Compulsive Inventory-Revised (OCI-R): validation of the German version in a sample of patients with OCD, anxiety disorders, and depressive disorders. J Anxiety Disord. 2008;22(4):734-49. 11. Smári J, Ólason DT, Eypórsdóttir A, Frölunde MB. Psychometric properties of the Obsessive Compulsive Inventory-Revised among Icelandic college students. Scand J Psychol. 2007;48(2):127-33.

12. Tavares M. Entrevista clínica estruturada para diagnóstico dos Transtornos do Eixo I do DSM-IV - Edição do paciente, versão 2.0 (SCID-I/P, Versão 2.0). Brasília: Tradução brasileira, Instituto de Psicologia da Universidade de Brasília; 1996.
13. First MB, Spitzer RL, Gibbon M, Williams JBW. Structured clinical interview for DSM-IV axis I disorders - clinician version (SCID-CV). Washington (DC): American Psychiatric Press; 1997.

14. Asbahr FR, Lotufo Neto F, Turecki GX, Del Porto JA, Rodríguez LR, Baruzzi M, Lima MA, Gentil V. Escala Yale-Brown de Sintomas Obsessivo-Compulsivos, tradução brasileira, São Paulo; 1992.

15. Goodman WK, Price LH, Rasmussen SA, Mazure C, Fleischmann RL, Hill CL, Heninger GR, Charney DS. The Yale-Brown Obsessive-Compulsive Scale: I. Development, use, and reliability. Arch Gen Psychiatr. 1989;46(11):1006-11.

16. Gorenstein C, Andrade L. Validation of a Portuguese version of the Beck Depression Inventory and the State-Trait Anxiety Inventory in Brazilian subjects. Braz J Med Biol Res. 1996;29(4):453-7.

17. Beck AT, Ward CH, Mendelson M, Mock J, Eerbaugh J. An inventory for measuring depression. Arch Gen Psychiatry. 1961;4:53-63.

18. Beck AT, Epstein N, Brown G, Steer RA. An inventory for measuring clinical anxiety: psychometric properties. J Consult Clin Psych. 1988;56(6):893-7.

19. Braga D, Cordioli AV, Manfro GG. Cognitive-behavioral group therapy for obsessive-compulsive disorder: a 1 year follow-up. Acta Psychiatr Scand. 2005;112(3):180-6.

20. Cordioli AV, Heldt E, Bochi DB, Margis R, Sousa MB, Tonello JF, Manfro GG, Kapczinski F. Cognitive-behavioral group therapy in obsessive-compulsive disorder: a randomized clinical trial. Psychother Psychosom. 2003;72(4):211-6.

21. Sousa MB, Isolan LR, Oliveira RR, Manfro GG, Cordioli AV. A randomized clinical trial on cognitive-behavioral group therapy and sertraline in the treatment of obsessive-compulsive disorder. J Clin Psych. 2006;67(7):1133-9.

22. Cordioli AV, Heldt E, Bochi DB, Margis R, Sousa MB, Juliano F, Tonello JF, Teruchkin B, Kapczinski F. Cognitive-behavioral group therapy in obsessivecompulsive disorder: a clinical trial. Rev Bras Psiquiatr. 2002;24(3):113-20.

23. Souza FP, Foa EB, Meyer E, Niederauer KG, Raffin AL, Cordioli AV. Obsessive-Compulsive Inventory and Obsessive-Compulsive Inventory-Revised Scales: translation into Brazilian Portuguese and cross-cultural adaptation. Rev Bras Psiquiatr. 2008;30(1):42-6.

24. Abramowitz J, McKay D, Taylor S. Special series subtypes of obsessivecompulsive disorder. Behav Ther. 2005;36:367-9. 